\title{
Quantitation of Pyrrole-Imidazole Polyamide in Rat Plasma by High-Performance Liquid Chromatography Coupled with UV Detection
}

\author{
Tomonori Kamei, ${ }^{1}$ Takahiko Aoyama, ${ }^{1}$ Chihiro Tanaka, ${ }^{1}$ \\ Takafumi Nagashima, ${ }^{1}$ Yukio Aoyama, ${ }^{1}$ Hiroyuki Hayashi, ${ }^{2}$ Hiroki Nagase, ${ }^{3}$ \\ Takahiro Ueno, ${ }^{4}$ Noboru Fukuda, ${ }^{4}$ and Yoshiaki Matsumoto ${ }^{1}$ \\ ${ }^{1}$ Department of Clinical Pharmacokinetics, School of Pharmacy, Nihon University, 7-7-1 Narashinodai, Chiba, \\ Funabashi City 274-8555, Japan \\ ${ }^{2}$ Department of Clinical Pharmacotherapy, School of Pharmacy, Nihon University, 7-7-1 Narashinodai, Chiba, \\ Funabashi City 274-8555, Japan \\ ${ }^{3}$ Chiba Cancer Center Research Institute, 666-2, Nitonacho, Chuo-ku, Chiba, Chiba City 260-8717, Japan \\ ${ }^{4}$ Department of Medicine, School of Medicine, Nihon University, Tokyo 173-8610, Japan \\ Correspondence should be addressed to Yoshiaki Matsumoto, matsumoto.yoshiaki@nihon-u.ac.jp
}

Received 9 March 2012; Accepted 16 April 2012

Academic Editor: John B. Vincent

Copyright ( $\odot 2012$ Tomonori Kamei et al. This is an open access article distributed under the Creative Commons Attribution License, which permits unrestricted use, distribution, and reproduction in any medium, provided the original work is properly cited.

\begin{abstract}
A simple and robust method using high-performance liquid chromatography with UV detection was developed and validated for the determination of six pyrrole-imidazole (PI) polyamides (HN.49, TGF- $\beta 1 \mathrm{f}$, TGF- $\beta 1 \mathrm{t}$, HN.50f, HN.50t, and LOX-1) in rat plasma. After the plasma proteins were precipitated with methanol containing phenacetin as an internal standard, the analytes were separated on a Luna C18 (2) $(5 \mu \mathrm{m}, 4.6 \times 150 \mathrm{~mm})$. Calibration curves were linear over the range of 0.5 to $200 \mu \mathrm{g} / \mathrm{mL}$ for $\mathrm{HN}$.49, 0.25 to $200 \mu \mathrm{g} / \mathrm{mL}$ for TGF- $\beta 1 \mathrm{f}$, TGF- $\beta 1 \mathrm{t}$, HN.50t, and LOX-1, 1 to $200 \mu \mathrm{g} / \mathrm{mL}$ for HN.50f in rat plasma. The inter- and intraday precision were below $15 \%$, and the accuracy was within $15 \%$ at the quality controls. The validated method was successfully applied to sample analysis for the pharmacokinetic study.
\end{abstract}

\section{Introduction}

Pyrrole(Py)-imidazole(Im) (PI) polyamides are small synthetic molecules composed of aromatic rings of $\mathrm{N}$-methylpyrrole and $N$-methylimidazole amino acids [1]. Synthetic polyamides recognize and bind to specific nucleotide sequences in the minor groove of double-helical DNA with high affinity [2]. Various sequence-specific DNA-binding PI polyamides have been developed to regulate gene expression by targeting the promoter regions of enhancer and transcription factor-binding elements in vitro [3]. PI polyamide targeting rat transforming growth factor (TGF)- $\beta_{1}$ has been reported to inhibit the expressions of TGF- $\beta_{1}$ mRNA and protein in the renal cortext of Dahl-S rats. The targeted PI polyamide also reduced glomerulosclerosis and interstitial fibrosis without side effects. These observations indicate that PI polyamides will be effective for TGF- $\beta_{1}$-related diseases, including progressive renal injury $[4,5]$. PI polyamides targeting human aurora kinase A (AURKA) and B (AURKB) promoters significantly inhibited the promoter activities, and mRNA and protein expression levels of AURKA and AURKB. They also demonstrated a marked antiproliferative synergy in human tumor cell lines as a result of induction of apoptosis-mediated severe catastrophe of cell-cycle progression [6]. PI polyamides specifically inhibited lectin-like oxidized low-density lipoprotein receptor-1 mRNA expression and apoptosis induced by oxidized low-density lipoprotein and angiotensin II in human umbilical vein endothelial cells [7]. PI polyamide that targets the activator protein1-binding site of the matrix metalloproteinase (MMP)-9 
<smiles>CC(=O)Nc1cc(C(=O)Nc2cc(C(=O)NCCC(=O)Nc3cc(C(=O)Nc4cc(C(=O)NCCCC(=O)Nc5cn(C)c(C(=O)NCCC(=O)NCCCN(C)C)n5)n(C)c4)n(C)c3)n(C)c2)n(C)c1</smiles>

(a) PI polyamide HN.49

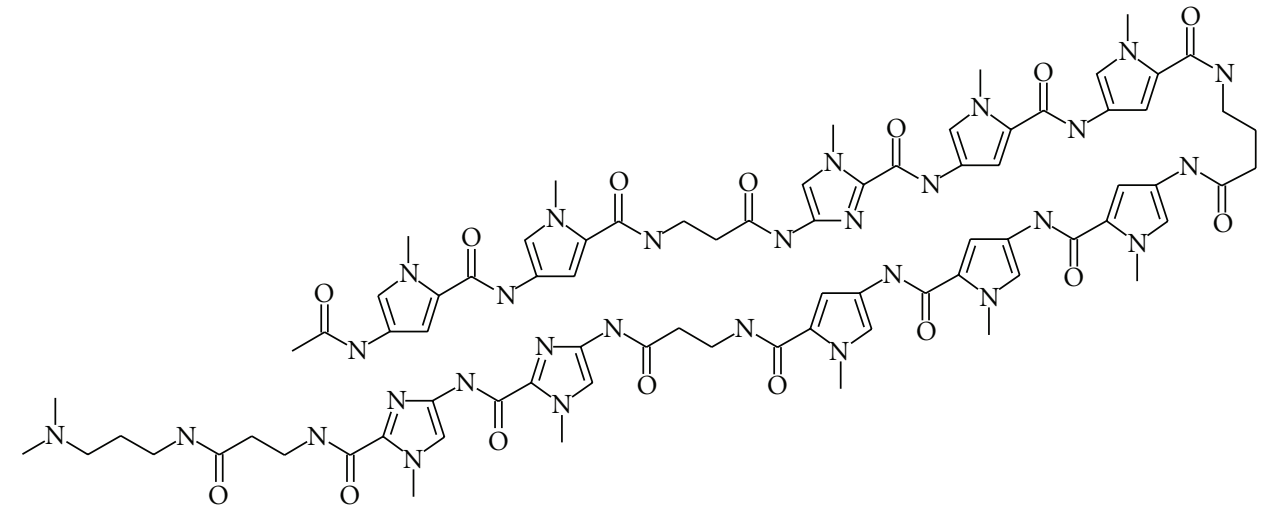

(b) PI polyamide TGF- $\beta 1 \mathrm{f}$<smiles>CC(=O)Nc1cc(C(=O)Nc2cc(C(=O)NCCC(=O)Nc3cn(C)c(C(=O)Nc4cc(C(=O)Nc5cc(C(=O)Nc6cc(NC(=O)c7cn(C)c(C(=O)NCCC(=O)NCCCN(C)C)n7)n(C)c6)n(C)c5)n(C)c4)n3)n(C)c2)n(C)c1</smiles>

(c) PI polyamide TGF- $\beta 1 \mathrm{t}$<smiles>CC(=O)Nc1cc(C(=O)Nc2cc(C(=O)NCCC(=O)Nc3cn(C)c(C(=O)Nc4cn(C)c(C(=O)Nc5cn(C)c(C(=O)Nc6cc(C(=O)NCCCC(=O)Nc7cn(C)c(C(=O)NCCC(=O)NCCCN(C)C)n7)n(C)c6)n5)n4)n3)n(C)c2)n(C)c1</smiles>

(d) PI polyamide HN.50f

Figure 1: Continued. 


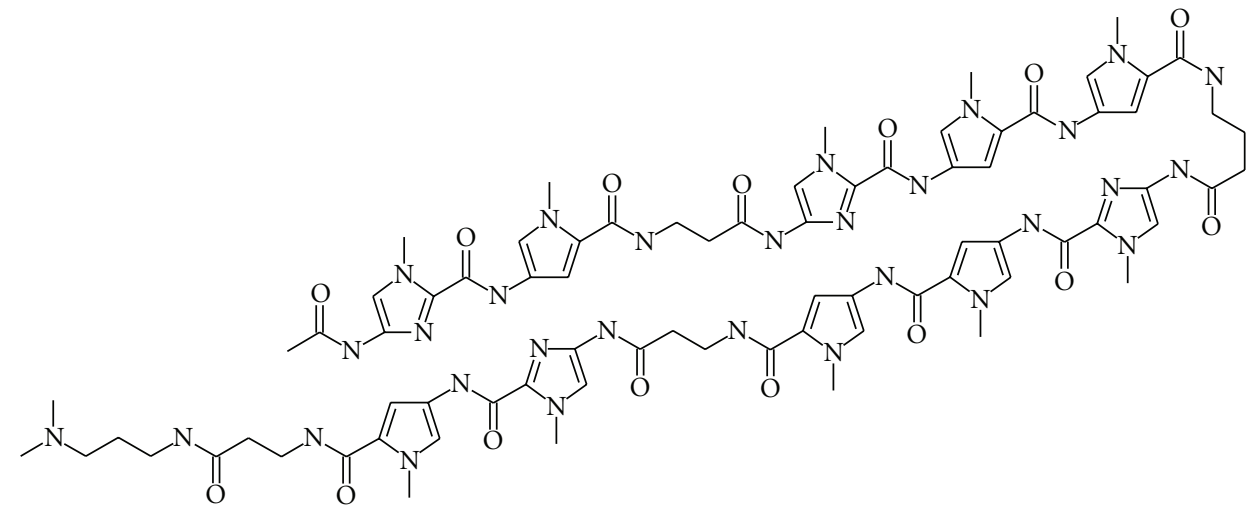

(e) PI polyamide HN.50t

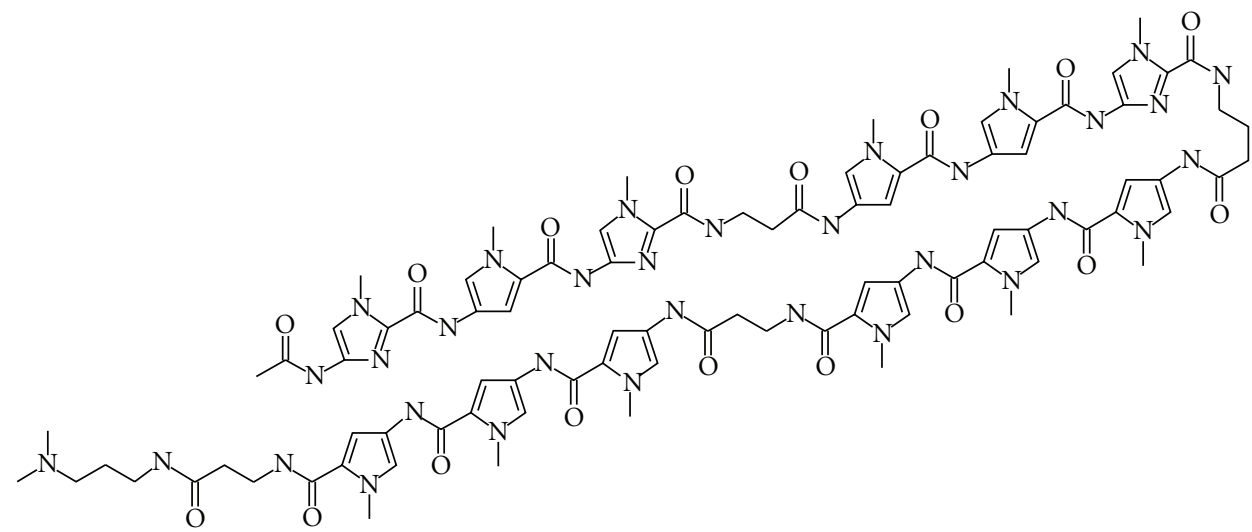

(f) PI polyamide LOX-1

FIgURE 1: Structures of PI polyamides.

promoter significantly inhibited MMP-9's mRNA expression, protein level, and enzymatic activity in human breast adenocarcinoma cells. The PI polyamide was quickly localized in mouse cellular nuclei of many tissues. Moreover, the polyamide treatment significantly decreased metastasis in a mouse model of liver metastasis [8]. From these observations, lots of PI polyamides have been identified as novel candidates for gene therapy.

We have already observed that pharmacokinetic profile of PI polyamide is related to their molecular weights $[9,10]$. It is crucial to elucidate a pharmacokinetic profile in early development of a compound. We have already reported bioanalytical method for the determination of some PI polyamides in rat plasma by using high-performance liquid chromatography (HPLC) [11], and in this paper, we show more simple and sensitive method using an internal standard (IS) that was developed for different sequence and longer PI polyamide. An IS is useful to compensate for the errors from sample preparation. If an IS is added at the beginning of sample preparation, it is possible to quantitate analytes of interest in more simple ways with robustness. We have developed and validated a new method using an IS for the quantitation of some PI polyamides in rat plasma at the lower limit quantitation of $0.25 \mu \mathrm{g} / \mathrm{mL}$, while it was $1 \mu \mathrm{g} / \mathrm{mL}$ in our previous method. The method was applied to the sample analysis for pharmacokinetic profile.

\section{Materials and Methods}

2.1. Chemicals and Reagents. PI polyamides (HN.49, TGF$\beta 1 \mathrm{f}$, TGF- $\beta 1 \mathrm{t}, \mathrm{HN} .50 \mathrm{f}, \mathrm{HN} .50 \mathrm{t}$, and LOX-1) were purchased from Gentier Biosystems Co., Ltd. (Kyoto, Japan). Chemical structures are presented in Figure 1. The compounds are in free forms. HPLC-grade methanol, HPLC-grade acetonitrile, and LC-MS-grade distilled water were purchased from Kanto Chemical Co., Inc. (Tokyo, Japan). Phenacetin was purchased from Sigma-Aldrich (Tokyo, Japan). All the other reagents used were of the highest quality and purchased from Wako Pure Chemical Industries, Ltd. (Tokyo, Japan).

2.2. Sample Preparation. Stock solutions of PI polyamides were prepared by dissolving the compounds in water to produce $2 \mathrm{mg} / \mathrm{mL}$ stock solutions. The solutions were stored at $-20^{\circ} \mathrm{C}$. Calibration standard and quality control (QC) samples were prepared mixed with $10 \mu \mathrm{L}$ of diluted stock solutions and $40 \mu \mathrm{L}$ of blank plasma. The samples were mixed 


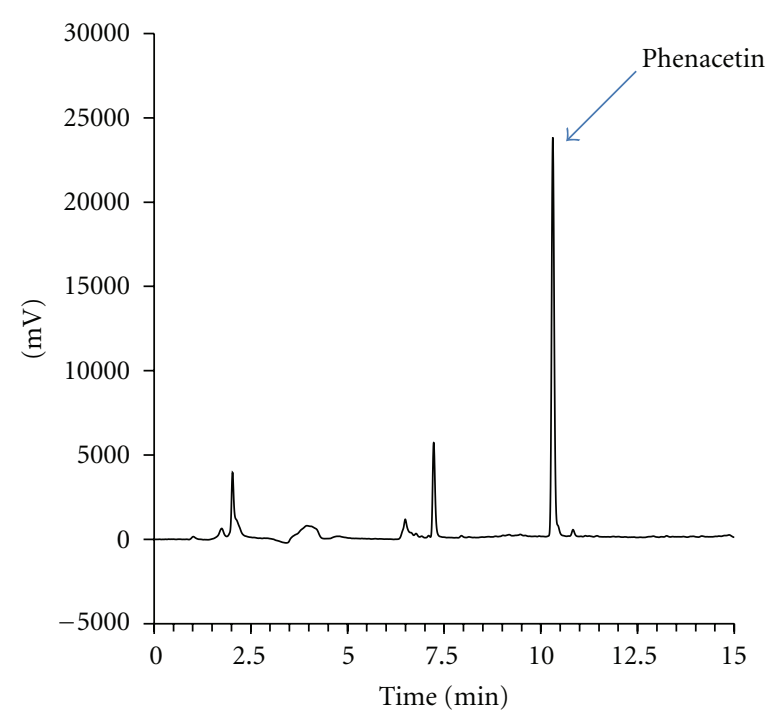

(a) Phenacetin

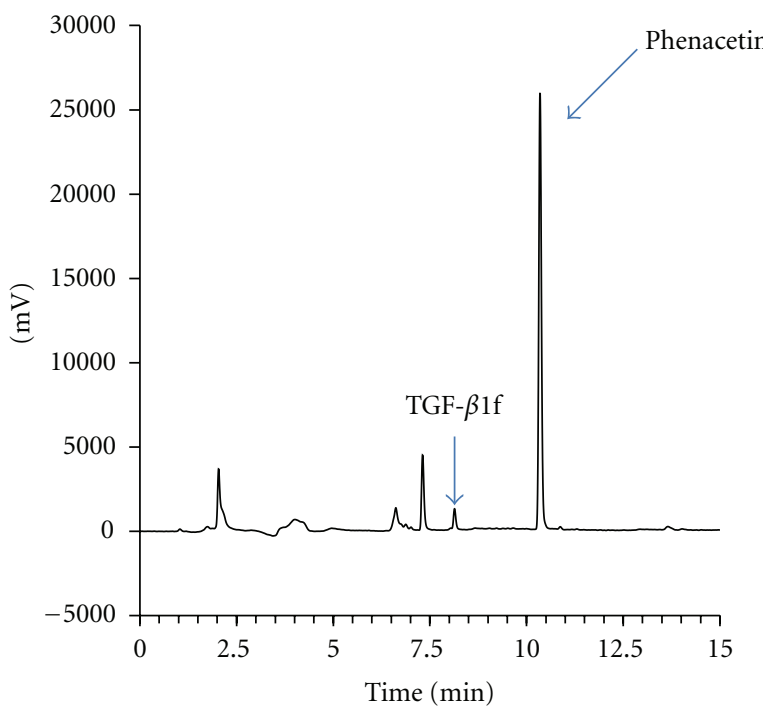

(c) Phenacetin+TGF- $\beta$ if

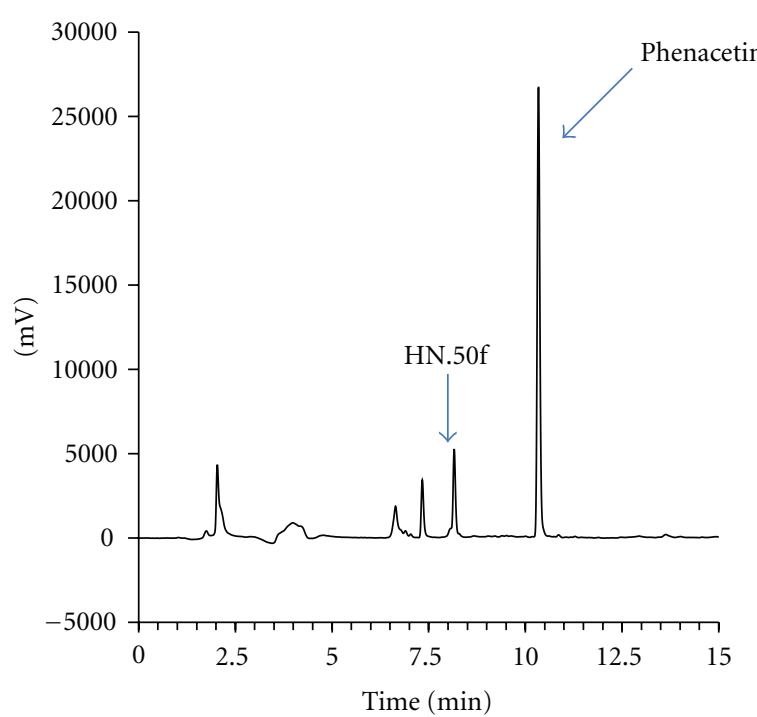

(e) Phenacetin+HN.50f

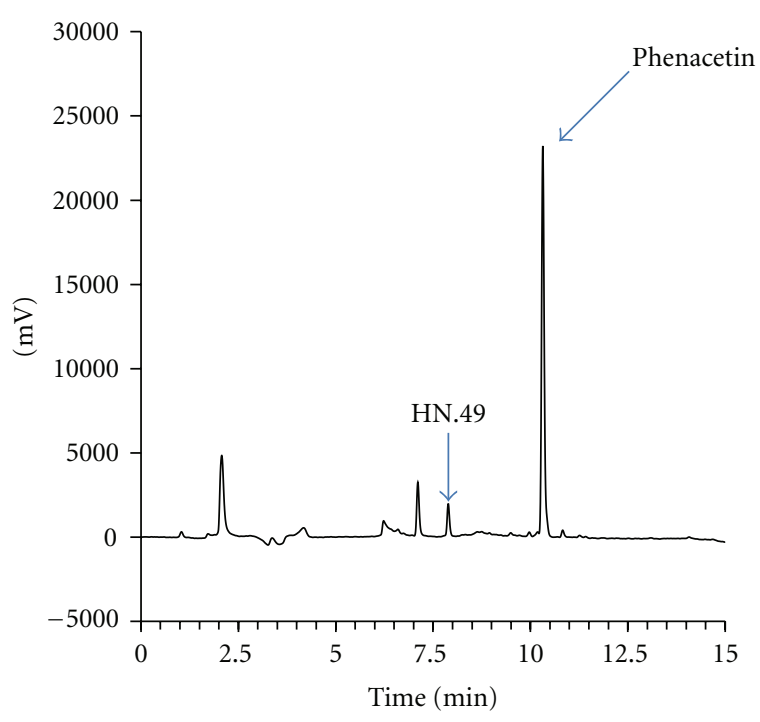

(b) Phenacetin+HN.49

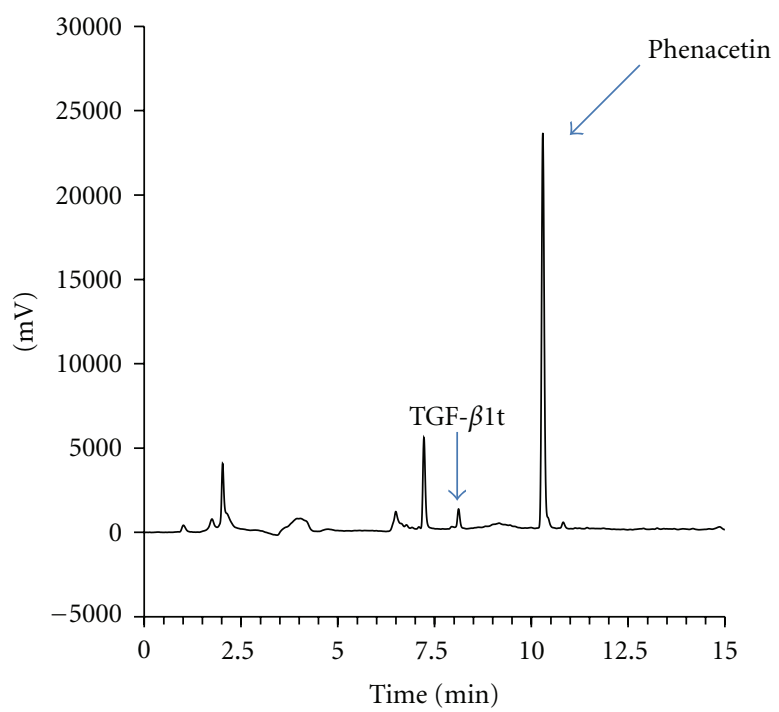

(d) Phenacetin+TGF- $\beta 1 \mathrm{t}$

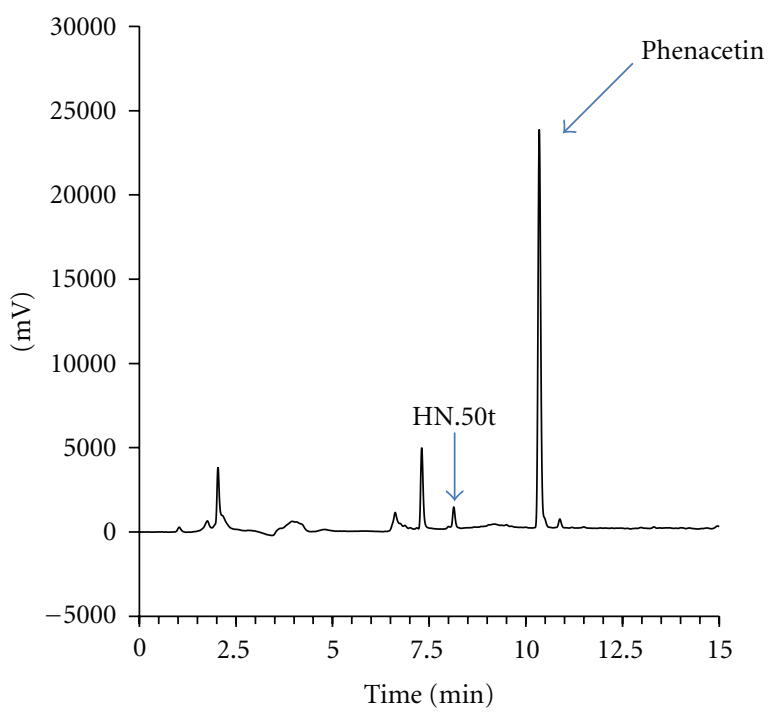

(f) Phenacetin+HN.50t

FIgUre 2: Continued. 


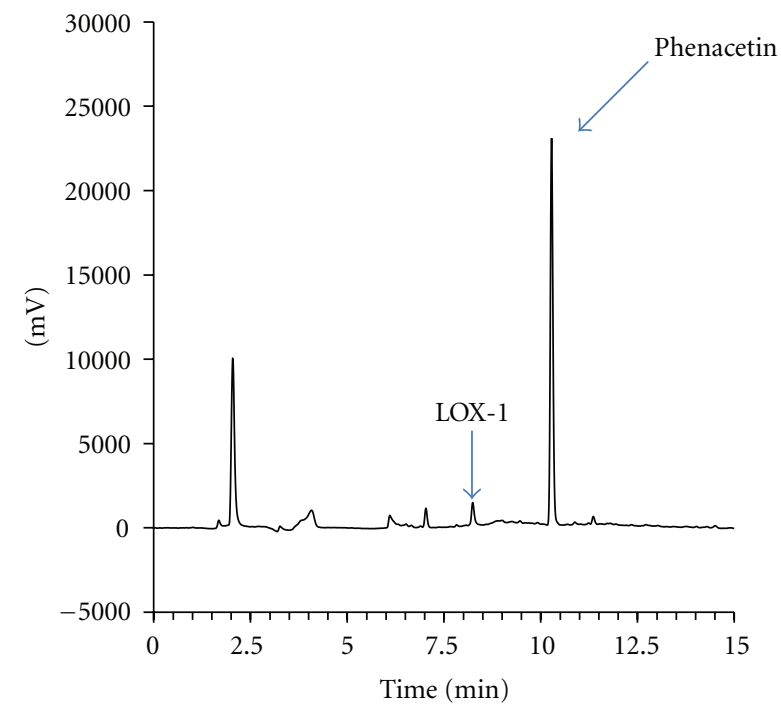

(g) Phenacetin+LOX-1

FIGURe 2: Representative chromatograms of PI polyamides at the LLOQs: (a) blank (with the IS), (b) HN.49, (c) TGF- $\beta 1 \mathrm{f}$, (d) TGF- $\beta 1 \mathrm{t}$, (e) HN.50f, (f) HN.50t, and (g) LOX-1.

with $100 \mu \mathrm{L}$ of methanol contained $1 \mathrm{mM}$ of phenacetin as an IS and vortexed. After centrifugation at $10,000 \mathrm{xg}$ for $5 \mathrm{~min}$ at $4^{\circ} \mathrm{C}$ twice, the supernatant was injected in HPLC system.

2.3. Chromatography Conditions. HPLC analysis was conducted on Shimadzu LC-20 chromatographs (Kyoto, Japan). PI polyamides and phenacetin were analyzed on a Luna C18 (2) $(5 \mu \mathrm{m}, 4.6 \times 150 \mathrm{~mm}$, Phenomenex $)$ column, maintained at $40^{\circ} \mathrm{C}$. The mobile phase consisted of $0.1 \%$ acetic acid (solvent A) and acetonitrile (solvent B) at a flow rate of $1.0 \mathrm{~mL} / \mathrm{min}$. The gradient started at the mobile phase A-B (100:0, v:v), changed linearly to A-B $(20: 80, \mathrm{v}: \mathrm{v})$ until $10 \mathrm{~min}$, washed with A-B $(20: 80, \mathrm{v}: \mathrm{v})$ until $15 \mathrm{~min}$. The autosampler was maintained at $4^{\circ} \mathrm{C}$. The injection volume was $30 \mu \mathrm{L}$. The detection wavelength was set at $310 \mathrm{~nm}$.

2.4. Validation Procedure. Validation was conducted according to the FDA guidance for bioanalytical method validation [12]. Selectivity was evaluated by confirming that there were no interference peaks at the retention time of PI polyamides in rat blank plasma and that there were sufficient separation of PI polyamides and phenacetin. Calibration curve linearity for PI polyamide was evaluated on three different days by preparing the samples each day. Calibration curves for PI polyamide were fitted by the least squares method (weighting of $1 / \mathrm{x}$ ) using the relationship between the ratio of the PI polyamide peak area to the IS peak area (peak area ratio) and the nominal analyte concentration. The criteria for the linearity of the calibration curves were defined as follows: the accuracy of the back-calculated values for the nonzero calibration standards should be within $\pm 15 \%( \pm 20 \%$ at the lower limit of quantitation (LLOQ)) and at least $75 \%$ of the nonzero calibration standards should meet the criteria, including at LLOQ and the upper limit of quantitation.
Intraday accuracy and precision were evaluated by analyzing five replicates at four different concentrations of QC samples. LLOQ, QL, QM, and QH, which relate to the lowest, lower, middle, and higher concentrations ranges for the linear region of the calibration curve, are used as QC samples. Interday accuracy and precision were evaluated by analyzing the QC samples on three different days. Accuracy, expressed as the relative error (RE), should be within $\pm 15 \%$ ( $\pm 20 \%$ for the LLOQ). Precision, expressed as the coefficient of variation $(\mathrm{CV})$, should be less than 15\% (20\% for the LLOQ).

Recovery was determined by comparing the absolute peak areas of the extracted QC samples with those of the neat solutions. Five replicates per sample were analyzed and the averages of the responses were used for the calculation.

Freezer storage stability and extracted sample stability were evaluated by analyzing QC samples stored under the relevant storage conditions in $n=5$. The criteria are defined as the RE of the mean should be within $\pm 15 \%$.

2.5. Animals and Drug Administration. Three to four male Wistar rats (280-320 g) were obtained from Sankyo Labo Service Corporation (Tokyo, Japan). They were maintained in a temperature-controlled room in a 12-h light-dark cycle and allowed free access to food and tap water. They were acclimatized for at least one week before the experiments. A polyethylene tube (SP45; $0.58 \mathrm{~mm}$ I.D., $0.96 \mathrm{~mm}$ O.D., Natsume Seisakusho Co., Ltd.) was inserted into the right jugular vein and left femoral artery of the rats under anesthesia with pentobarbital sodium (Kyoritsu Seiyaku Corporation). After cannulation, the rats were left alone for at least one night before the experiments. PI polyamide dissolved in water was administered intravenously into the jugular vein of the rats at a dose of $3.0 \mathrm{mg} / \mathrm{kg}$. Blood samples 
TABLE 1: Back calculated concentrations of the calibration curves of PI polyamides in rat plasma.

\begin{tabular}{|c|c|c|c|c|c|c|c|c|}
\hline HN.49 & & & & & & & & \\
\hline Nominal concentration $(\mu \mathrm{g} / \mathrm{mL})$ & 0.5 & 1 & 5 & 10 & 20 & 50 & 100 & 200 \\
\hline $\begin{array}{l}\text { Observed concentration } \\
(\text { mean of } n=3, \mu \mathrm{g} / \mathrm{mL})\end{array}$ & 0.52 & 0.92 & 4.73 & 10.03 & 21.09 & 51.03 & 102.78 & 194.12 \\
\hline Accuracy $(\%)$ & 4.4 & -8.4 & -5.3 & 0.3 & 5.4 & 2.1 & 2.8 & -2.9 \\
\hline Precision $(\%)$ & 2.4 & 4.5 & 9.3 & 1.4 & 0.2 & 2.8 & 2.2 & 5.9 \\
\hline TGF- $\beta 1 \mathrm{f}$ & & & & & & & & \\
\hline Nominal concentration $(\mu \mathrm{g} / \mathrm{mL})$ & 0.25 & 0.5 & 2 & 5 & 20 & 50 & 100 & 200 \\
\hline $\begin{array}{l}\text { Observed concentration } \\
(\text { mean of } n=3, \mu \mathrm{g} / \mathrm{mL})\end{array}$ & 0.27 & 0.43 & 1.72 & 4.78 & 21.51 & 50.94 & 107.30 & 204.81 \\
\hline Accuracy $(\%)$ & 7.9 & -13.2 & -14.2 & -4.4 & 7.5 & 1.9 & 7.3 & 2.4 \\
\hline Precision (\%) & 0.8 & 1.2 & 0.1 & 5.6 & 1.8 & 1.3 & 2.0 & 1.0 \\
\hline TGF- $\beta 1 \mathrm{t}$ & & & & & & & & \\
\hline Nominal concentration $(\mu \mathrm{g} / \mathrm{mL})$ & 0.25 & 0.5 & 2 & 5 & 20 & 50 & 100 & 200 \\
\hline $\begin{array}{l}\text { Observed concentration } \\
(\text { mean of } n=3, \mu \mathrm{g} / \mathrm{mL})\end{array}$ & 0.26 & 0.47 & 2.01 & 5.31 & 20.39 & 50.71 & 98.07 & 191.09 \\
\hline Accuracy $(\%)$ & 2.9 & -6.7 & 0.6 & 6.1 & 1.9 & 1.4 & -1.9 & -4.5 \\
\hline Precision $(\%)$ & 1.5 & 4.0 & 2.1 & 1.3 & 3.5 & 2.0 & 1.6 & 6.1 \\
\hline HN.50f & & & & & & & & \\
\hline Nominal concentration $(\mu \mathrm{g} / \mathrm{mL})$ & 1 & 2 & 5 & 10 & 20 & 50 & 100 & 200 \\
\hline $\begin{array}{l}\text { Observed concentration } \\
(\text { mean of } n=3, \mu \mathrm{g} / \mathrm{mL})\end{array}$ & 1.04 & 1.85 & 5.13 & 9.49 & 20.48 & 51.02 & 103.47 & 196.96 \\
\hline Accuracy $(\%)$ & 3.6 & -7.5 & 2.7 & -5.1 & 2.4 & 2.1 & 3.5 & -1.5 \\
\hline Precision $(\%)$ & 3.1 & 4.5 & 7.8 & 4.0 & 1.5 & 0.7 & 2.1 & 3.1 \\
\hline HN.50t & & & & & & & & \\
\hline Nominal concentration $(\mu \mathrm{g} / \mathrm{mL})$ & 0.25 & 0.5 & 2 & 5 & 20 & 50 & 100 & 200 \\
\hline $\begin{array}{l}\text { Observed concentration } \\
(\text { mean of } n=3, \mu \mathrm{g} / \mathrm{mL})\end{array}$ & 0.26 & 0.47 & 1.89 & 5.06 & 20.53 & 53.40 & 102.25 & 190.47 \\
\hline Accuracy $(\%)$ & 3.9 & -6.7 & -5.4 & 1.3 & 2.6 & 6.8 & 2.3 & -4.8 \\
\hline Precision (\%) & 2.4 & 4.6 & 2.0 & 3.9 & 3.5 & 7.2 & 4.5 & 3.9 \\
\hline LOX-1 & & & & & & & & \\
\hline Nominal concentration $(\mu \mathrm{g} / \mathrm{mL})$ & 0.25 & 0.5 & 2 & 5 & 20 & 50 & 100 & 200 \\
\hline $\begin{array}{l}\text { Observed concentration } \\
(\text { mean of } n=3, \mu \mathrm{g} / \mathrm{mL})\end{array}$ & 0.26 & 0.47 & 1.91 & 5.11 & 20.98 & 51.39 & 101.43 & 190.59 \\
\hline Accuracy $(\%)$ & 3.0 & -5.3 & -4.3 & 2.1 & 4.9 & 2.8 & 1.4 & -4.7 \\
\hline Precision $(\%)$ & 0.9 & 1.3 & 4.3 & 1.6 & 2.2 & 2.4 & 2.0 & 3.5 \\
\hline
\end{tabular}

$(0.5 \mathrm{~mL})$ were collected into heparinized $1.5 \mathrm{~mL}$ microtubes at 0 and $300 \mathrm{~min}$ after administration. After sampling, the collected blood was replaced with an equal volume of saline. Plasma was separated by centrifugation at $10000 \mathrm{xg}$ and $4^{\circ} \mathrm{C}$ for $10 \mathrm{~min}$, then stored at $-20^{\circ} \mathrm{C}$ until use. The animal study was approved by the Animal Ethics Committee of the College of Pharmacy, Nihon University.

\section{Results and Discussion}

3.1. Chromatography. UV wavelength was determined at $310 \mathrm{~nm}$ as previously reported [11]. Phenacetin was used as an IS for robust quantitation with simple sample preparation. Representative chromatograms of PI polyamides at the
LLOQ are presented in Figure 2. The peaks of PI polyamides and phenacetin were observed at the retention times of 8.1 min and 10.3 min with sufficient separation. No interference peak was observed on the retention times in the developed conditions.

3.2. Method Validation. The mean of the back-calculated concentrations over three days, the accuracy and precision are presented in Table 1. Calibration curve linearity was good over the range of 0.5 to $200 \mu \mathrm{g} / \mathrm{mL}$ for HN.49, 0.25 to $200 \mu \mathrm{g} / \mathrm{mL}$ for TGF- $\beta 1 \mathrm{f}$, TGF- $\beta 1 \mathrm{t}$, HN.50t, and LOX-1, 1 to $200 \mu \mathrm{g} / \mathrm{mL}$ for HN.50f in rat plasma.

Accuracy and precision of the assay for the determination of PI polyamides in rat plasma were presented in Table 2. 
TABLE 2: Intra-day and inter-day accuracy and precision of QC samples for PI polyamides in rat plasma.

\begin{tabular}{|c|c|c|c|c|c|c|c|c|}
\hline \multirow{3}{*}{$\begin{array}{l}\text { HN.49 } \\
\begin{array}{l}\text { Nominal concentration } \\
(\mu \mathrm{g} / \mathrm{mL})\end{array}\end{array}$} & \multicolumn{4}{|c|}{ Intraday $(n=5)$} & \multicolumn{4}{|c|}{ Interday $(n=15)$} \\
\hline & LLOQ & QL & QM & $\mathrm{QH}$ & LLOQ & QL & QM & $\mathrm{QH}$ \\
\hline & 0.5 & 1 & 100 & 160 & 0.5 & 1 & 100 & 160 \\
\hline $\begin{array}{l}\text { Observed concentration } \\
\text { (mean, } \mu \mathrm{g} / \mathrm{mL})\end{array}$ & 0.49 & 0.86 & 104.03 & 144.73 & 0.52 & 0.90 & 103.54 & 154.50 \\
\hline Accuracy (\%) & -1.2 & -14.4 & 4.0 & -9.6 & 3.8 & -10.2 & 3.5 & -3.4 \\
\hline Precision (\%) & 2.8 & 1.1 & 2.2 & 1.1 & 5.3 & 7.2 & 2.0 & 5.2 \\
\hline \multicolumn{9}{|l|}{ TGF- $\beta 1 \mathrm{f}$} \\
\hline & \multicolumn{4}{|c|}{ Intra-day $(n=5)$} & \multicolumn{4}{|c|}{ Inter-day $(n=15)$} \\
\hline \multirow{2}{*}{$\begin{array}{l}\text { Nominal concentration } \\
(\mu \mathrm{g} / \mathrm{mL})\end{array}$} & LLOQ & QL & QM & $\mathrm{QH}$ & LLOQ & QL & QM & QH \\
\hline & 0.25 & 0.5 & 100 & 160 & 0.25 & 0.5 & 100 & 160 \\
\hline $\begin{array}{l}\text { Observed concentration } \\
\text { (mean, } \mu \mathrm{g} / \mathrm{mL} \text { ) }\end{array}$ & 0.23 & 0.43 & 109.03 & 160.89 & 0.25 & 0.45 & 104.28 & 159.49 \\
\hline Accuracy $(\%)$ & -9.1 & -13.9 & 9.0 & 0.6 & 1.2 & -10.6 & 4.3 & -0.3 \\
\hline Precision (\%) & 3.4 & 1.6 & 0.9 & 1.9 & 9.3 & 6.3 & 5.2 & 1.8 \\
\hline \multicolumn{9}{|l|}{ TGF- $\beta 1 \mathrm{t}$} \\
\hline & \multicolumn{4}{|c|}{ Intra-day $(n=5)$} & \multicolumn{4}{|c|}{ Inter-day $(n=15)$} \\
\hline \multirow{2}{*}{$\begin{array}{l}\text { Nominal concentration } \\
(\mu \mathrm{g} / \mathrm{mL})\end{array}$} & LLOQ & QL & QM & QH & LLOQ & QL & QM & $\mathrm{QH}$ \\
\hline & 0.25 & 0.5 & 100 & 160 & 0.25 & 0.5 & 100 & 160 \\
\hline $\begin{array}{l}\text { Observed concentration } \\
(\text { mean, } \mu \mathrm{g} / \mathrm{mL})\end{array}$ & 0.24 & 0.43 & 101.52 & 147.62 & 0.23 & 0.43 & 100.70 & 149.11 \\
\hline Accuracy (\%) & -4.7 & -13.4 & 1.5 & -7.7 & -7.4 & -14.4 & 0.7 & -6.8 \\
\hline Precision (\%) & 9.5 & 4.7 & 4.5 & 0.4 & 11.9 & 4.1 & 3.9 & 1.9 \\
\hline \multicolumn{9}{|l|}{ HN.50f } \\
\hline & \multicolumn{4}{|c|}{ Intra-day $(n=5)$} & \multicolumn{4}{|c|}{ Inter-day $(n=15)$} \\
\hline \multirow{2}{*}{$\begin{array}{l}\text { Nominal concentration } \\
(\mu \mathrm{g} / \mathrm{mL})\end{array}$} & LLOQ & QL & QM & QH & LLOQ & QL & QM & QH \\
\hline & 1 & 2 & 100 & 160 & 1 & 2 & 100 & 160 \\
\hline $\begin{array}{l}\text { Observed concentration } \\
\text { (mean, } \mu \mathrm{g} / \mathrm{mL})\end{array}$ & 1.09 & 1.76 & 109.24 & 172.59 & 1.08 & 1.86 & 107.07 & 171.06 \\
\hline Accuracy (\%) & 9.4 & -11.9 & 9.2 & 7.9 & 7.5 & -6.8 & 7.1 & 6.9 \\
\hline Precision (\%) & 3.3 & 1.2 & 1.7 & 1.8 & 3.9 & 4.2 & 4.2 & 3.6 \\
\hline \multicolumn{9}{|l|}{ HN.50t } \\
\hline & \multicolumn{4}{|c|}{ Intra-day $(n=5)$} & \multicolumn{4}{|c|}{ Inter-day $(n=15)$} \\
\hline \multirow{2}{*}{$\begin{array}{l}\text { Nominal concentration } \\
(\mu \mathrm{g} / \mathrm{mL})\end{array}$} & LLOQ & QL & QM & $\mathrm{QH}$ & LLOQ & QL & QM & $\mathrm{QH}$ \\
\hline & 0.25 & 0.5 & 100 & 160 & 0.25 & 0.5 & 100 & 160 \\
\hline $\begin{array}{l}\text { Observed concentration } \\
(\text { mean, } \mu \mathrm{g} / \mathrm{mL})\end{array}$ & 0.25 & 0.43 & 97.49 & 143.77 & 0.25 & 0.44 & 97.71 & 149.61 \\
\hline Accuracy (\%) & 0.4 & -14.2 & -2.5 & -10.1 & 0.6 & -13.0 & -2.3 & -6.5 \\
\hline Precision (\%) & 7.7 & 2.6 & 3.6 & 1.8 & 9.0 & 4.5 & 4.4 & 3.4 \\
\hline \multicolumn{9}{|l|}{ LOX-1 } \\
\hline & \multicolumn{4}{|c|}{ Intra-day $(n=5)$} & \multicolumn{4}{|c|}{ Inter-day $(n=15)$} \\
\hline \multirow{2}{*}{$\begin{array}{l}\text { Nominal concentration } \\
(\mu \mathrm{g} / \mathrm{mL})\end{array}$} & LLOQ & QL & QM & $\mathrm{QH}$ & LLOQ & QL & QM & $\mathrm{QH}$ \\
\hline & 0.25 & 0.5 & 100 & 160 & 0.25 & 0.5 & 100 & 160 \\
\hline $\begin{array}{l}\text { Observed concentration } \\
(\text { mean, } \mu \mathrm{g} / \mathrm{mL})\end{array}$ & 0.24 & 0.45 & 97.93 & 144.45 & 0.25 & 0.45 & 98.95 & 145.94 \\
\hline Accuracy (\%) & -2.9 & -10.9 & -2.1 & -9.7 & -1.1 & -10.6 & -1.1 & -8.8 \\
\hline Precision (\%) & 2.4 & 2.9 & 2.5 & 2.6 & 4.5 & 2.0 & 4.0 & 6.4 \\
\hline
\end{tabular}


Table 3: Recovery.

\begin{tabular}{|c|c|c|c|c|}
\hline HN.49 & & & & \\
\hline \multirow{2}{*}{ Nominal concentration $(\mu \mathrm{g} / \mathrm{mL})$} & LLOQ & QL & QM & $\mathrm{QH}$ \\
\hline & 0.5 & 1 & 100 & 160 \\
\hline Recovery (\%) & 85.6 & 107 & 91.7 & 93.3 \\
\hline Precision (\%) & 11.4 & 8.6 & 4.6 & 9.6 \\
\hline \multicolumn{5}{|l|}{ TGF- $\beta 1 \mathrm{ff}$} \\
\hline \multirow{2}{*}{ Nominal concentration $(\mu \mathrm{g} / \mathrm{mL})$} & LLOQ & QL & QM & $\mathrm{QH}$ \\
\hline & 0.25 & 0.5 & 100 & 160 \\
\hline Recovery (\%) & 76.3 & 101 & 101 & 98.8 \\
\hline Precision (\%) & 3.6 & 2.2 & 3.8 & 2.4 \\
\hline \multicolumn{5}{|l|}{ TGF- $\beta 1 \mathrm{t}$} \\
\hline \multirow{2}{*}{ Nominal concentration $(\mu \mathrm{g} / \mathrm{mL})$} & LLOQ & QL & QM & $\mathrm{QH}$ \\
\hline & 0.25 & 0.5 & 100 & 160 \\
\hline Recovery (\%) & 101 & 96.5 & 98.2 & 101 \\
\hline Precision (\%) & 7.8 & 2.5 & 1.2 & 3.2 \\
\hline \multicolumn{5}{|l|}{ HN.50f } \\
\hline \multirow{2}{*}{ Nominal concentration $(\mu \mathrm{g} / \mathrm{mL})$} & LLOQ & QL & QM & $\mathrm{QH}$ \\
\hline & 1 & 2 & 100 & 160 \\
\hline Recovery (\%) & 99.2 & 92.1 & 88.2 & 89.7 \\
\hline Precision (\%) & 3.0 & 5.3 & 0.8 & 9.4 \\
\hline \multicolumn{5}{|l|}{ HN.50t } \\
\hline \multirow{2}{*}{ Nominal concentration $(\mu \mathrm{g} / \mathrm{mL})$} & LLOQ & QL & QM & $\mathrm{QH}$ \\
\hline & 0.25 & 0.5 & 100 & 160 \\
\hline Recovery (\%) & 87.2 & 84.4 & 95.6 & 96.7 \\
\hline Precision (\%) & 10.1 & 8.2 & 1.2 & 4.3 \\
\hline \multicolumn{5}{|l|}{ LOX-1 } \\
\hline \multirow{2}{*}{ Nominal concentration $(\mu \mathrm{g} / \mathrm{mL})$} & LLOQ & QL & QM & $\mathrm{QH}$ \\
\hline & 0.25 & 0.5 & 100 & 160 \\
\hline Recovery (\%) & 78.3 & 80.6 & 92.7 & 85.8 \\
\hline Precision (\%) & 4.2 & 1.0 & 1.4 & 2.7 \\
\hline
\end{tabular}

Accuracy and precision were evaluated to establish the method reproducibility. Intraday and interday accuracy were within $-14.4 \%$ to $9.4 \%$ and $-14.4 \%$ to $7.5 \%$, respectively. Intraday and interday precision were less than $9.5 \%$ and $11.9 \%$, respectively. All the accuracy values were within $\pm 15 \%$, and all the precision values were less than $15 \%$.

The recovery data are presented in Table 3 . The investigation was conducted at the same concentrations of QC samples from five replicates. The recoveries of PI polyamides ranged from $76.3 \%$ to $107 \%$. All the precision values were less than $11.4 \%$. These results suggested that developed extraction method was consistent and reproducible.

3.3. Stability. The stability results are presented in Table 4 . The study was conducted using low- and high-QC samples (QL and $\mathrm{QH})$ to evaluate the stability of the extracted samples in the autosampler tray at $4^{\circ} \mathrm{C}$ for 24 hours and their freezer storage stability at $-20^{\circ} \mathrm{C}$ for 14 days. All results were within $15 \%$ of the nominal values, showing sufficient stability for sample analysis and storage.

3.4. Application to Rat Plasma Sample Analysis. The validated method was successfully applied to the sample analysis. All extractions and analyses were conducted under secure and stable conditions. The mean plasma concentration-time profiles after the intravenous administration of PI polyamides at a dose of $3.0 \mathrm{mg} / \mathrm{kg}$ are shown in Figure 3. Although HN.49 was below the LLOQ at most of the time points of blood collection, the sensitivity of the quantitation of other PI polyamides was sufficient to evaluate the plasma concentrationtime profiles of the compounds. As we have already observed, molecular weights of the PI polyamide are thought to be related to their pharmacokinetic profiles $[9,10]$. Additionally, it was suggested that combination of the Py and Im were also related to the unique pharmacokinetic profiles judging from the results of HN.50t and HN.50f, and that of TGF- $\beta 1 \mathrm{t}$ and TGF- $\beta 1 \mathrm{f}$, which are almost the same molecular weights.

\section{Conclusions}

A simple and robust HPLC method was developed and validated for the determination of PI polyamides in rat plasma, and applied to the sample analysis after intravenous administration of PI polyamides. The observed pharmacokinetic profiles were unique and they are thought to be related to their molecular weights and the combination of Py and 
TABLE 4: Stability.

\begin{tabular}{|c|c|c|c|}
\hline & Nominal concentration $(\mu \mathrm{g} / \mathrm{mL})$ & Extracted sample in auto sampler $\left(4^{\circ} \mathrm{C}, 24 \mathrm{hrs}\right)$ & Freezer storage $\left(-20^{\circ} \mathrm{C}, 14\right.$ days $)$ \\
\hline & & $\operatorname{RE}(\%)$ & $\mathrm{RE}(\%)$ \\
\hline \multirow{2}{*}{ HN.49 } & QL (1) & 7.8 & 14.0 \\
\hline & $\mathrm{QH}(160)$ & 2.1 & 7.6 \\
\hline \multirow{2}{*}{ TGF- $\beta 1 \mathrm{f}$} & QL (0.5) & 1.5 & 6.0 \\
\hline & QH (160) & -3.0 & 13.2 \\
\hline \multirow{2}{*}{ TGF- $\beta 1 \mathrm{t}$} & $\mathrm{QL}(0.5)$ & -2.8 & 2.8 \\
\hline & $\mathrm{QH}(160)$ & -0.9 & -1.4 \\
\hline \multirow{2}{*}{ HN.50f } & QL (2) & -5.4 & -1.8 \\
\hline & QH (160) & -1.1 & -5.6 \\
\hline \multirow{2}{*}{ HN.50t } & $\mathrm{QL}(0.5)$ & -1.8 & -1.4 \\
\hline & QH (160) & -1.9 & -1.4 \\
\hline \multirow{2}{*}{ LOX-1 } & $\mathrm{QL}(0.5)$ & -7.5 & 3.2 \\
\hline & $\mathrm{QH}(160)$ & -3.8 & 12.4 \\
\hline
\end{tabular}

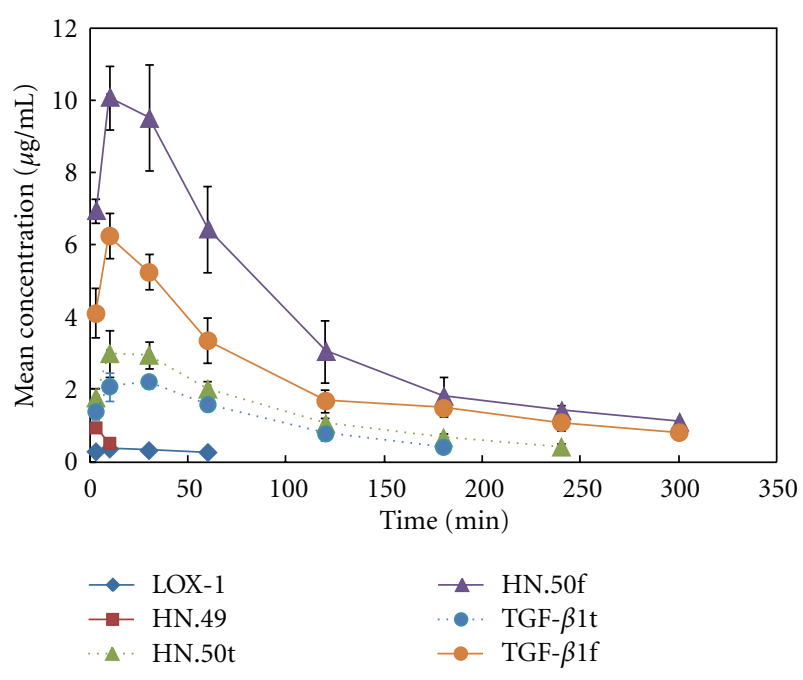

FIGURE 3: Plasma concentration-time profile of PI polyamides in rats after administration. Each data point represents the mean \pm $\mathrm{SD}$ of three to four rats.

Im as well. PI polyamides have been identified as novel candidates for gene therapy, and evaluation of the pharmacokinetic profile of the compounds is quite important for the development.

\section{Acknowledgment}

This work was partially supported by a grant from the Strategic Research Base Development Program for Private Universities subsidized by MEXT (2011).

\section{References}

[1] J. W. Trauger, E. E. Baird, and P. B. Dervan, "Recognition of DNA by designed ligands at subnanomolar concentrations," Nature, vol. 382, no. 6591, pp. 559-561, 1996.
[2] D. S. Pilch, N. Poklar, C. A. Gelfand et al., "Binding of a hairpin polyamide in the minor groove of DNA: sequence-specific enthalpic discrimination," Proceedings of the National Academy of Sciences of the United States of America, vol. 93, no. 16, pp. 8306-8311, 1996.

[3] M. S. R. C. Murty and H. Sugiyama, "Biology of N-methylpyrrole-N-methylimidazole hairpin polyamide," Biological and Pharmaceutical Bulletin, vol. 27, no. 4, pp. 468-474, 2004.

[4] H. Matsuda, N. Fukuda, T. Ueno et al., "Development of gene silencing pyrrole-imidazole polyamide targeting the TGF- $\beta 1$ promoter for treatment of progressive renal diseases," Journal of the American Society of Nephrology, vol. 17, no. 2, pp. 422432, 2006.

[5] H. Matsuda, N. Fukuda, T. Ueno et al., "Transcriptional inhibition of progressive renal disease by gene silencing pyrrole-imidazole polyamide targeting of the transforming growth factor- $\beta 1$ promoter," Kidney International, vol. 79, no. 1, pp. 46-56, 2011.

[6] T. Takahashi, Y. Asami, E. Kitamura et al., "Development of pyrrole-imidazole polyamide for specific regulation of human aurora kinase-A and -B gene expression," Chemistry and Biology, vol. 15, no. 8, pp. 829-841, 2008.

[7] T. Ueno, N. Fukuda, A. Tsunemi et al., "A novel gene silencer, pyrrole-imidazole polyamide targeting human lectin-like oxidized low-density lipoprotein receptor-1 gene improves endothelial cell function," Journal of Hypertension, vol. 27, no. 3, pp. 508-516, 2009.

[8] X. Wang, H. Nagase, T. Watanabe et al., "Inhibition of MMP-9 transcription and suppression of tumor metastasis by pyrroleimidazole polyamide," Cancer Science, vol. 101, no. 3, pp. 759$766,2010$.

[9] A. Fukasawa, T. Aoyama, T. Nagashima et al., "Pharmacokinetics of pyrrole-imidazole polyamides after intravenous administration in rat," Biopharmaceutics and Drug Disposition, vol. 30, no. 2, pp. 81-89, 2009.

[10] T. Nagashima, T. Aoyama, T. Yokoe et al., "Pharmacokinetic modeling and prediction of plasma pyrrole-imidazole polyamide concentration in rats using simultaneous urinary and biliary excretion data," Biological and Pharmaceutical Bulletin, vol. 32, no. 5, pp. 921-927, 2009. 
[11] A. Fukasawa, T. Nagashima, T. Aoyama et al., "Optimization and validation of a high-performance liquid chromatographic method with UV detection for the determination of pyrroleimidazole polyamides in rat plasma," Journal of Chromatography B, vol. 859, no. 2, pp. 272-275, 2007.

[12] Guidance for Industry, Bioanalytical Method Validation, Food and Drug Administration Center for Drug Evaluation and Research (CDER), Center for Veterinary Medicine (CVM), 2001. 

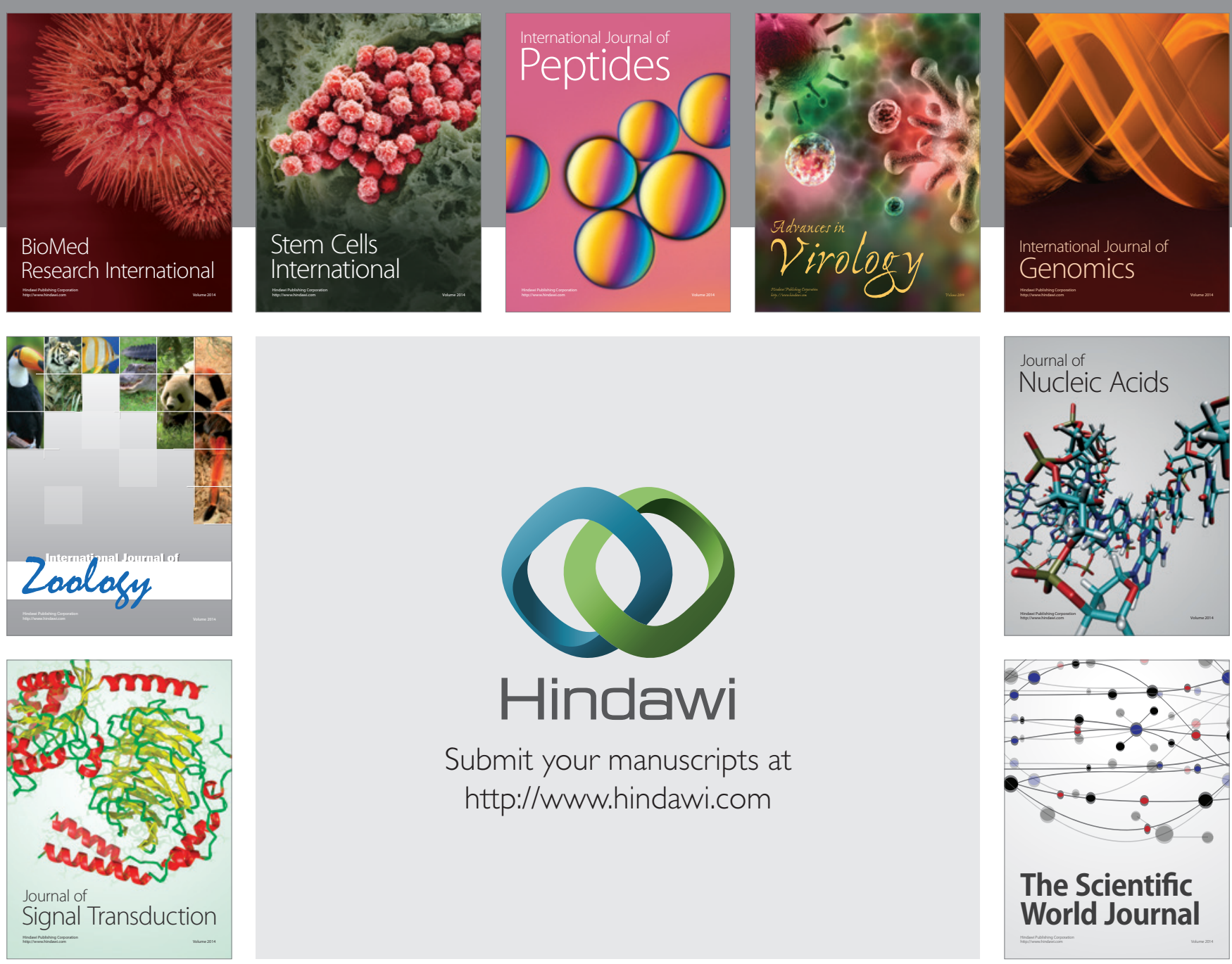

Submit your manuscripts at

http://www.hindawi.com
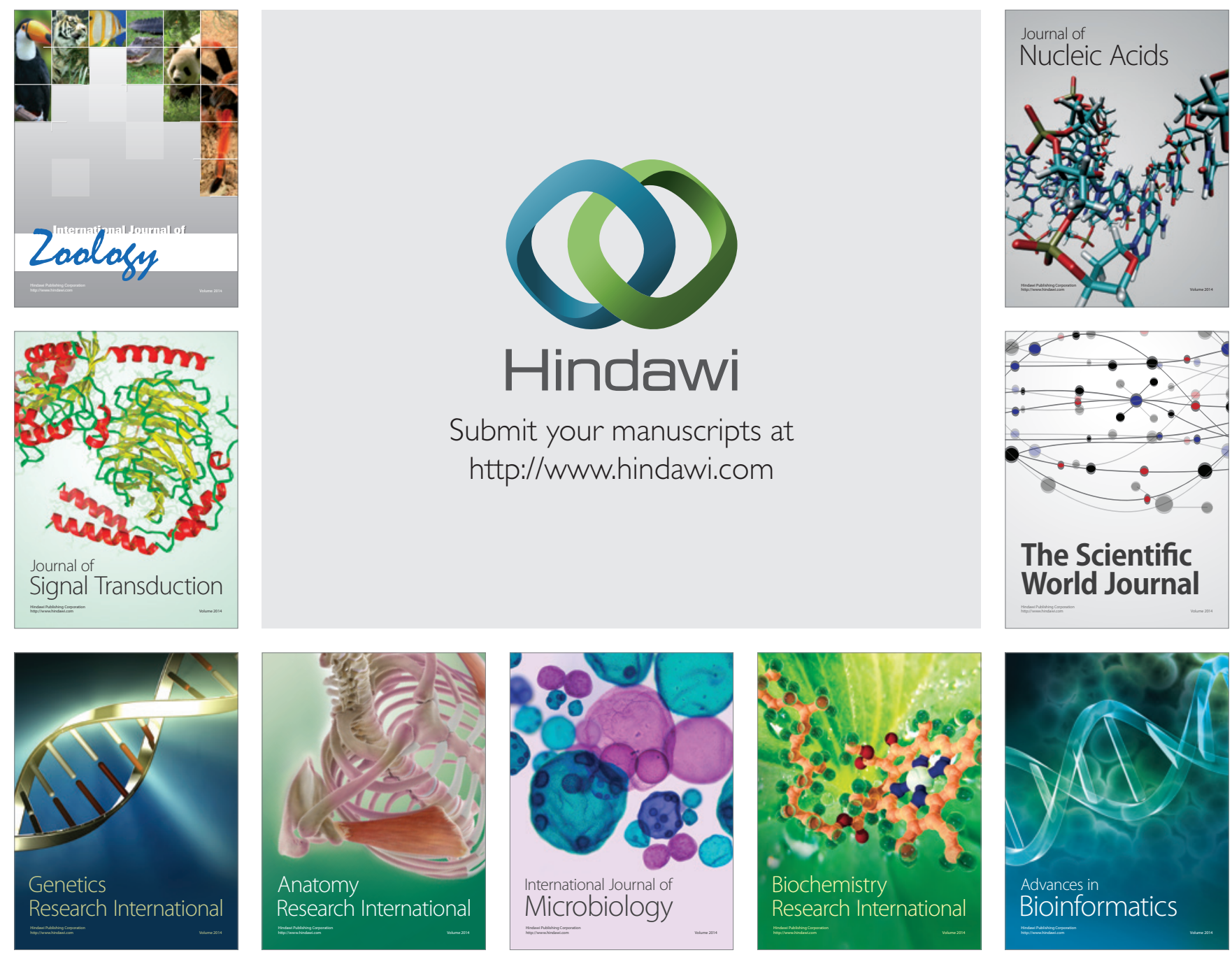

The Scientific World Journal
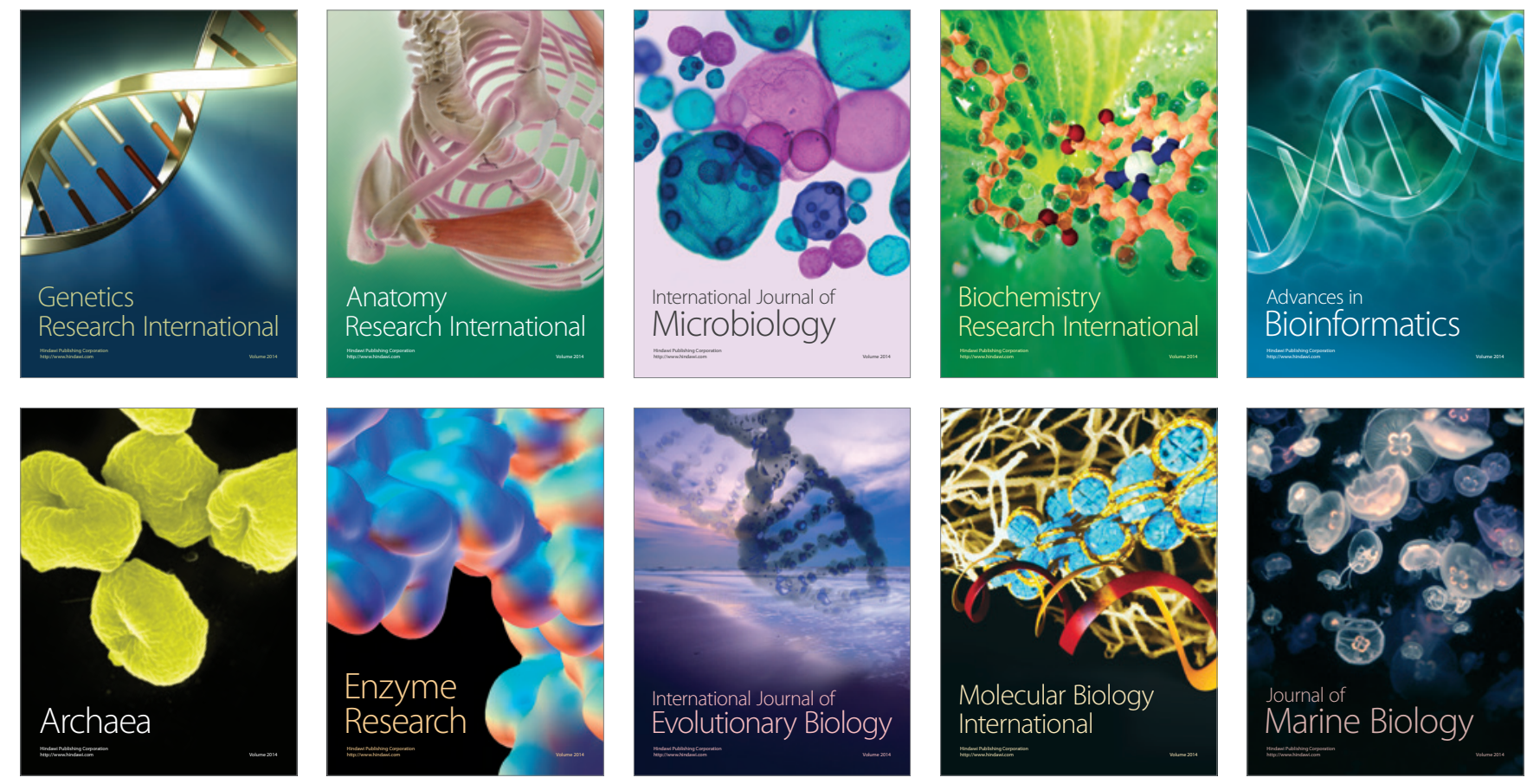